\title{
CHIRONOMID MIDGE SWARMS ASSOCIATED WITH SLOW SAND FILTRATION WORKS
}

\author{
By P. D. Armitage, J. H. B. Blackburn and I. T. Harris
}

CEH Dorset (Formerly the Institutes of Terrestrial Ecology and Freshwater Ecology). Winfrith Technology Centre, Corchester, Dorset DT2 8ZD, UK

The mass emergence of chironomid midges frequently causes problems to people living next to freshwater habitats. A local water company, Bournemouth and West Hampshire Water (BWHW), operate slow sand filters for drinking water treatment beside the River Abon at Mill Road, Christchurch and at Francis Avenue, Bournemouth. In recent years, there have been increased incidences of swarms of midges occurring at such densities as to cause problems to local residents, particularly those occupying new housing developments near the slow sand filters.

The emergence of large numbers of midges results in swarms which are carried or are attracted to, nearby housing. It has not been possible to predict the occurrence of these swarms due to a lack of basic ecological data linked to operational procedures and timing. The project is funded by BWHW and is attempting to determine the chironomid faunal composition and the identity of nuisance species at the two locations, initially over a period of one year. We are also investigating the life-history of the dominant species and trapping adults to determine emergence time and the distribution of adults around the sites. These data will be linked to information on filter bed operation and local weather conditions.

In general terms, the filter beds represent temporary water bodies. The beds are verticalsided rectangular ponds which have a base of porous concrete overlain with gravel and then by a thick layer of sand which is smoothed and levelled to produce a flat homogeneous bottom. The depth of water is also uniform at about $1 \mathrm{~m}$, depending on operational practice. The continuous supply of water carrying particulate matter, which is trapped at the sand surface, provides a rich source of food for organisms resulting in the build up of large populations of oligochaetes (worms), 
nematodes, protozoans and chironomid midge larvae. Periodically the beds are emptied (about every 12 weeks at Christchurch and over 20 weeks at Bournemouth) and the filtering medium cleaned, thus only organisms which can complete their development within the period the beds are run can maintain populations. Chironomid midges are well adapted to survive in such environments.

Of the twenty-three taxa recorded from the filter beds only seven were common Ablabesmyia monilis, Macropelopia nebulosa, Cricotopus (Isocladius) sp.? tricinctus, Psectrocladius barbimanus, Orthocladius glabripennis, Micropsectralindrothi, and Tanytarsus gregarius/inaequalis. Of these only the Tanytarsini and Orthocladius glabripennis occurred in large enough numbers to cause a nuisance.

The filter beds at both Christchurch and Bournemouth are characterised by their long periods of operation. At Bournemouth the mean bed run for the filters which were sampled, was approximately 150 days and at Christchurch the period was shorter (105 days - based on previous run times). These periods are up to three times longer than at the Thames Water Works at Ashford Common where the longest run observed during our 1990 study was 74 days and the mean 29 days (WOTTON et al 1992). The implications of this are that complex communities can develop in the beds with many overlapping generations. In the summer periods chironomid species can complete their development in as little as 17 days. In beds which are run for periods of less than 30 days only one generation of these species would be able to complete their life cycle. In addition, longer bed runs allow colonisation by a wide range of species and the Bournemouth and Christchurch beds supported a pond-like fauna. These characteristics have made it difficult to estimate the development time of individual taxa as one generation overlaps the other and there is continual recruitment from egglaying females. At the same time the relative complexity of the community has prevented dominance by one generation which can lead to mass emergence. However post-winter conditions (increase in light and temperature) result in maturation of the community as a whole and it is at these times that mass emergence, resulting in large swarms, has occurred in recent years. The perception of these swarms as nuisance is determined largely by the wind speed and direction which control movement off site towards residential areas.

This study will continue through the summer and end in October. In the meantime I would be interested to hear of any other similar investigations in other parts of the world. Slow sand filters provide an environment to examine both basic ecological aspects (competition, resource use, adaptation, distribution, behaviour of adults and larvae) and applied problems (filtration rates, water quality, nuisance problems etc.) and can provide a rich source of information on chironomid ecology and behaviour (WOTTON \& ARMITAGE 1994).

\section{References:}

Wotton, R.S., Armitage, P.D., Aston, K., BLACKBURN, J.H., HAMBURGER, M. \& WOODWAR, C.A. (1992). Colonization and emergence of midges (Chironomidae: Diptera) in slow sand filter beds. Netherlands Journal of Aquatic Ecology, 26(2-4): 331-339.

Wotton R. S. \& ARmitage P. D. (1994). Size of midges (Diptera: Chironomidae) emerging from newly-filled ponds. In: Chironomids from genes to ecosystems (ed. P. S. CRANSTON): 355-361, CSIRO Publications.

Patrick Armitage

CEH Dorset (Formerly the Institutes of Terrestial Ecology and Freshwater Ecology) Winfrith Technology Centre Dorchester Dorset DT2 8ZD UK email:pdar@ceh.ac.uk www.ceh.ac.uk 